九州大学学術情報リポジトリ

Kyushu University Institutional Repository

Sage Ladies, Devoted Brides: The Kara monogatari as a Manual for Women's Correct Behavior?

MIGLIORE, CHIARA MARIA

University of Salento : Associate Prosessor of Japanese Language and Literature

https://doi.org/10.5109/2794920

出版情報: Journal of Asian Humanities at Kyushu University. 5, pp.81-95, 2020-03. Kyushu University, School of Letters, Graduate School of Humanities, Faculty of Humanities バージョン:

権利関係 : 


\title{
Sage Ladies, Devoted Brides: The Kara monogatari as a Manual for Women's Correct Behavior?
}

\author{
MARIA CHIARA MIGLIORE
}

I

$\mathrm{N}$ recent decades, scholars have sought to highlight the importance of Japanese works written in Chinese, which traditionally were marginalized and treated independently from what was considered Japanese literature. More recently, the Western academy has succeeded in overcoming the long-standing wakan 和漢 dichotomy that has prevailed in analyses of Japanese literature. ${ }^{1}$ As has been pointed out, Chinese writing endured as the core of literacy in Heian Japan (794-1185), where kanbun 漢文 was the main medium of the learned not only at court but also at the periphery, ${ }^{2}$ while it is also evident that Japanese authors wrote their own literature through and against Chinese literary precedents. ${ }^{3}$ The irreducible hybridity of the wa-kan

The author is grateful to Rajyashree Pandey and Michel VieillardBaron for their helpful comments and suggestions on previous drafts of this article, and would like to thank the editors and anonymous readers for their thoughtful comments.

1 The term wa-kan (literally "Japan and China") has been traditionally used by Japanese scholars to oppose the "extraneous" Chinese to the "indigenous" Japanese. However, the expression, which has been in use since the Heian period, at that time did not mean an opposition but rather a juxtaposition, a combination of two styles of writing expressing one literary culture, formed through the continuous appropriation and negotiation of Chinese and Japanese elements. Considered in this sense, "Sino-Japanese literature" could be a useful translation.

2 Smits, "The Way of the Literati."

3 Denecke, Classical World Literatures. cultural system is today accepted and understood as a self-contained tradition, a rich cultural sphere drawing on Japanese personal, political, ethical, religious, and cultural identity obtained after a process of inclusion, omission, or rejection of Chinese cultural elements. ${ }^{4}$

This wa-kan cultural system, which initially belonged primarily to the aristocratic elite, spread to the military classes through a process of popularization and through the use of the Japanese language. At the beginning of the Kamakura period (1185-1333), we find the shogunate's administrative elite engaged in the reading of Chinese didactic texts offering political, cultural, and literary arguments, which they translated into Japanese to help the spread of the wa-kan cultural system to the newly emerging samurai class. However, the first example of the popularization of wa-kan culture can be found earlier, at the end of Heian period, in the form of a text called the Kara monogatari 唐物語 (Chinese Tales).

This collection of secular anecdotes from Chinese literary and historical sources is not simply a translation of some of the most famous Chinese tales, but sheds light on the precise process through which Chinese texts were made available to larger audiences, as

\footnotetext{
4 For an overview of the debate on the wa-kan issue, see Persiani, "China as Self, China as Other."
} 
Chinese sources were manipulated in order to bring the stories closer to the aesthetic tastes of the author's readership. In this article, I will first discuss the genre of the Kara monogatari; traditionally, it has been considered a collection of setsuwa 説話 (anecdotes), but considering the importance of its didactic aims and its influence on the production of vernacular literary and practical knowledge manuals in the subsequent Kamakura period, I suggest that it can be considered a primer. The Kara monogatari is primarily occupied with the promotion of Confucian virtues, mainly those regarding the correct behavior of women, such as fidelity, wisdom, and forbearance. Love stories also play an important role: here again a didactic aim can be observed, as love is described as a hindrance to spiritual elevation. One of the stories, for example, even criticizes Daoist beliefs and reconfigures the Chinese original which emphasizes the value of renunciation, instead presenting love as a despicable obstacle to rebirth in the Pure Land. The content of the stories, the rhetorical style typical of post-Genji monogatari 源氏物語 (The Tale of Genji, early eleventh century) novels, the Buddhist flavor in some of the anecdotes keeping with the kana literary vogue, and the Buddhist worldview that dominated the late Heian period - these are all features that lead me to speculate that the collection might well have been composed for female audiences, who scholars have supposed were no longer able to read or study Chinese.

\section{The Kara monogatari and the Question of Its Genre}

In 1954, while the scholar Ōta Shōjirō was examining the Sōka shoshi 桑華書誌 (Chinese and Japanese Bibliographic Notes, 1704-1723) written by bibliophile Maeda Tsunanori 前田綱紀 (1643-1724), he came across an ancient book catalogue. It was identified as a copy of a list of the books belonging to Prince Shukaku 守覚 (1150-1202), dating from the period from 1151 to 1187. The prince was the son of the sovereign, Goshirakawa 後白河 (1127-1192), and was living as a monk at the Ninna 仁和 monastery of Kyoto. This catalogue, which Ōta called Koseki kasho mokuroku 古蹟歌書目 録 (Ancient Manuscript Catalogue of Works on Japanese Poetry), contains the following note: "Kara mo- nogatari, one book, author: Shigenori." 5 This discovery put an end to the debate on the attribution and therefore the dating of the Kara monogatari, a work that had been reproduced in numerous handwritten and printed copies but could not be dated due to the lack of clues in the copies themselves or in other contemporary or later works. ${ }^{6}$

Scholars agree on the authorship of Fujiwara no Shigenori 藤原成範 (1135-1187), a poet and official, also known as the Middle Councilor of the Cherry Orchard District (Sakuramachi chūnagon 桜町中納言) because of his fondness for cherry trees, large quantities of which he planted in his garden.

Shigenori hailed from an illustrious literary family. His grandfather, Fujiwara no Sanekane 藤原実兼 (1085-1112), is said to have edited the Gōdanshō 江談 抄 (The Ōe Conversations, between 1104 and 1111?). His father, Fujiwara no Michinori 藤原通憲 (1106?-1159), rose rapidly during the reign of Goshirakawa and was famous for his erudition and as an author of historical works. Michinori owned a library containing almost two hundred Chinese works, as attested by the Tsüken $n y \bar{u} d \bar{o} z \bar{o} s h o$ mokuroku 通建入道蔵書目録 (Catalogue of the Works in Fujiwara no Michinori's Library, end of the twelfth century?) which, despite its incomplete

5 漢物語一帖成範作 Ōta, "'Sōka shoshi' shosai 'Koseki kasho mokuroku,"' p. 175.

6 The word kara, which from the third to sixth centuries denoted the southern part of the Korean Peninsula and later the continent as a whole, was represented by a number of Chinese characters: 伽羅 (phonetically), 韓, 唐, and 漢. It is commonly thought that the catalogue found by Ōta refers to the Kara monogatari discussed here. The Kara monogatari manuscripts sometimes have the title written in hiragana (から) and sometimes with the graph 唐, which by the late Heian period had become the most commonly used Chinese character to denote China. The oldest manuscript bears the title Mōgyū waka 蒙求和歌 (Japanese Poems on the Meng qiu, 1204), an erroneous reference (for more on this work, see below). The translations given in this article are based on this handwritten copy, considered by lkeda to be the text closest to the original. It is called the Sonkeikakubon 尊経閣 本, because it belongs to the Maeda family's Sonkeikaku Library in Tokyo. It dates back to the end of the Kamakura period and was perhaps made by Prince Takayoshi 尊良 (1310?-1336?) son of the sovereign Godaigo 後醍醐 (1288-1339). See Ikeda, Nitchū hikaku bungaku no kiso kenkyū, pp. 44-46. In addition to the family of texts that sprang from this copy, Ikeda found two others, which he called B and C; but neither present significant differences with respect to the Sonkeikakubon. See Fujiwara no Shigenori, Kōhon Kara monogatari. The terms kara monogatari 唐物語 (Chinese tales) or kara monogatari e 唐物語絵 (Chinese illustrated tales), which frequently appear in works from the late Heian period, refer more generally to Chinese anecdotes and legends also widely known in Japan from ancient times. 
transmission, is still the oldest existing catalogue of a private library in Japan.

Shigenori was not as famous as his father, but carried on the family tradition, making an even more prestigious career for himself: at his death he was a councilor and held the senior second rank (shōnii 正二位) at court. Given the scarcity of other information concerning his life and work, it is impossible to establish with certainty either the date of Kara monogatari's composition, its purpose, or the type of readers Shigenori was writing for. However, we can venture some hypotheses based on the content of the work. It is a collection of twenty-seven anecdotes from the Chinese tradition, written in the vernacular of the time, with each anecdote accompanied by one or more waka 和歌. The stories are of varying lengths and concern both real and legendary Chinese figures from the most distant past up to the Tang period (618-907). Given the anecdotal and didactic character of the work, the presence of a closing judgment in some stories, and the appearance of the term mukashi 昔 ("the past") at the opening of each tale, it has been classified as belonging to the anecdotal genre.

Collections of anecdotes were especially popular in the second half of the twelfth century. Beginning with Konjaku monogatarishū 今昔物語集 (Tales of Times Now Past, twelfth century), there was a proliferation of homiletic and didactic collections based on Buddhist religious propaganda. This followed a tradition that began in the Nara period with Nihon ryōiki 日本霊異記 (Supernatural and Extraordinary Chronicles of Japan, between 810 and 824) and then continued into the Heian period with the Sanbōe kotoba 三宝絵詞 (The Three Jewels, Illustrated, 984), in which some of the Nihon ryōiki anecdotes were translated and adapted.

At least two of these medieval collections, the Konjaku monogatarish $\bar{u}$ and the lesser-known Uchigikish $\bar{u}$ 打聞集 (Collection of Stories Heard, 1134?), contain entire books dedicated to stories originally written in Chinese and translated into Japanese. Whereas these translations were made in a religious context, the Kara monogatari is the first example of a translation from Chinese into Japanese of stories from the Confucian tradition, a secular domain unconnected with Buddhism. There are homiletic comments included in some anecdotes (for example, in anecdotes 18 and 27), but they were added by Shigenori and are not part of the original stories.

While the formal structure of setsuwa does not leave space for the inclusion of waka, this is not the case with the Kara monogatari. This aspect would therefore appear to bring the work closer to uta monogatari 歌 物語 (poetic stories) such as the Ise monogatari 伊勢 物語 (Tales of Ise, tenth century) or the Yamato monogatari 大和物語 (Tales of Yamato, tenth century). Nevertheless, as Midorikawa points out, unlike in the uta monogatari, most of the waka found in the Kara monogatari are not recited by the protagonists of the stories; rather, they express the feelings of Shigenori himself. ${ }^{7}$

One of the major poetic genres of the medieval period consisted of waka about ancient Chinese figures or historical events (kankojidai 漢故事題). The most significant work in this vein is the Kankoji waka shū 漢 故事和歌集 (Anthology of Japanese Poems Associated with Chinese Tales, Muromachi period), a collection of seventy poems divided into thirty-six subjects (or dai 題), all about figures from Chinese antiquity. Its content is largely the same as that of Kara monogatari, suggesting a link between the work and collections of poetry on specific themes of the medieval period. ${ }^{8}$

While Midorikawa proposes defining Kara monogatari as consisting of "anecdotes translated from Chinese” (hon'yaku shōsetsu 翻訳小説, probably referring to the Chinese xiao shuo 小説), ${ }^{9}$ Ikeda speaks of a "collection of monogatari translated from Chinese having the form of poetic stories" (uta monogatari no katachi o toru hon'yaku monogatarishu 歌物語の形 をとる翻訳物語集). ${ }^{10}$ Ultimately, however, the Kara monogatari cannot be clearly classified as belonging to a specific genre.

The Kara monogatari is not only difficult to classify but also complex to interpret. Attempts to understand its structure according to the principles of progression and association, which would make it similar to uta monogatari, or even on the basis of a "circular" construction, which would make it similar to some collections of setsuwa, ${ }^{11}$ are doomed to failure. Furthermore, the hypothesis put forward by Kobayashi, which unsuccessfully tries to order the stories based on the principle

\footnotetext{
7 Midorikawa, Kara monogatari, p. 536

8 Mimura, "Kankojidai waka kara mita chūsei ruidaishū no keifu."

9 Midorikawa, Kara monogatari, p. 540.

10 Ikeda, Nitchū hikaku bungaku no kiso kenkyū, p. 17.

11 Geddes, Kara monogatari: Tales of China, pp. 26-44. This is the only translation of the Kara monogatari in the English language. An Italian translation is in Migliore, Kara monogatari: Racconti cinesi.
} 
of the author's compassion (nasake 情) for all human feeling or conduct, is not convincing. ${ }^{12}$

Even if the question of genre remains unanswered, it is possible to establish the text's audience with some degree of certainty by considering the ethical value of the stories, whose strong didactic aim can be understood as an attempt to model women's behavior according to Confucian virtues.

\section{Didactic Translations: The Kara monogatari as a Primer}

In the first half of the ninth century, the works of the Chinese poet Bai Juyi 白居易 (772-846) reached Japan and were so influential that scholars tend to divide Japanese poetic output into two phases: before and after Bai Juyi. ${ }^{13}$ Of the twenty-seven stories contained in the Kara monogatari, six are rewritings of the works of Bai Juyi; moreover, they represent the most successful anecdotes from a literary point of view. These are Bai Juyi's most famous and quoted works in Japanese literature, and they include the Song of the Lute (Pipa xing 琵琶行, anecdote 2); the poem about Lady Li (Li furen 李夫人, anecdote 15); and lastly the Song of Everlasting Regret (Chang hen ge 長恨歌, anecdote 18), which narrates the romance between Yang Guifei 楊貴妃 (719756) and Tang Emperor Xuanzong 玄宗 (685-762). This is the central and most substantial episode in the collection and is even considered a monogatari in its own right, as there are handwritten and printed copies that contain only this anecdote. (For a list of anecdotes and their sources, see table 1.)

The other anecdotes are taken from numerous and varied sources. Some sources are historical, such as Shi $j i$ 史記 (Records of the Great Historian, second century BCE) by Sima Qian 司馬遷 (145?-86? BCE) and the annals of the Jin and Han dynasties, while others are collections of anecdotes that had been circulating in Japan since the Nara period, including some lost in China. These anecdotes contain characters, legends, and famous proverbs known to all and are among the most frequently quoted in Chinese and Japanese literature; they were studied at the State Academy (daigakuryō 大 学寮) and in private institutes, and were the subject of cultured, playful conversation. Ultimately they became iconic, forming a tradition that continued through the nineteenth century. They are so famous that they have essentially become stereotypes: as Richard Bowring

12 Kara monogatari zenshaku, pp. 308-17.

13 Konishi, A History of Japanese Literature, pp. 150-55. points out, they are "a sort of Fuji and geishas in reverse." ${ }^{14}$

Ten of are also found in the Meng qiu 蒙求 (Inquiries of the Ignorant, 746), ${ }^{15}$ the well-known manual dedicated to teaching children Chinese, attributed to an author of the Tang period, Li Han 李瀚, who seemingly flourished in the Tianbao era (742-756). The work contains 592 anecdotes set out in parallel verses of four characters per anecdote. Each verse contains the name of a historical or mythical personage dating from antiquity up to the sixth century. Thus, the Meng qiu was not only a means of teaching the Chinese language, but it also provided some information about history and culture: we might say that the work represents a sort of encyclopedia of Chinese civilization. Li Han also added some commentary to the text as an essential aid to understanding the anecdotes. The extreme regularity of the verses (which also rhyme) makes for easy memorization, which is the key to the success of the manual, a success that would soon spread beyond Chinese borders.

We do not know exactly when the Meng qiu came to Japan. It is first mentioned in a Japanese text in an entry of Nihon sandai jitsuroku 日本三代実録 (Veritable Record of Three Reigns of Japan, 901), which reports that on the twenty-fifth day of the eighth month of the year 878, Prince Sadayasu 貞保親王 (870-924), the eight-year-old son of Seiwa Tennō 清和天皇 (850881), began his studies of it. ${ }^{16}$ The work was a teaching instrument of primary importance not only for the princes, but also for the offspring of aristocratic families. Knowledge of Chinese language and culture was considered a fundamental part of the curriculum of any good state official, as a proverb popular in the Heian period reminds us:

The Kangakuin ${ }^{17}$ sparrows chirp the Meng qiu. ${ }^{18}$

\footnotetext{
14 Bowring, "Review," p. 586.

15 The expression meng qiu is taken from the Yijing 易経 (The Classic of Changes, probably written between the Spring and Autumn period [771-476 BCE] and the Warring States period [4O3-221 BCE]): "It is not I who seek the uncultivated; it is the uncultivated who seek me." Much later, Xu Ziguang 徐子光, a literary figure active in the twelfth century, wrote an excellent commentary that became so popular as to eclipse the previous ones. It is not known when Xu Ziguang's commentary reached Japan, but the oldest copy dates to 1239. The Meng qiu with Xu's commentary continued to be widely used throughout the Edo period and even during the Meiji era.

16 皇弟貞保親王於飛鳥舎初讀蒙求. Nihon sandai jitsuroku, p. 499.

17 The Kangakuin was the Institute of Higher Studies founded by Fujiwara no Fuyutsugu 藤原冬嗣 (775-826) in 812 for the education of Fujiwara family scions.

18 勧学院の雀は蒙求をさえずる. The proverb is preserved, for example, in the Hōbutsushū 宝物集 (Collection of Treasures, ca. 1180) anecdote collection. See Taira no Yasuyori, Hōbutsushū, p. 54.
} 
Table 1. List of Kara monogatari's twenty-seven anecdotes, their sources, and their corresponding entries in Meng qiu. The asterisks in the righthand column designate anecdotes that tell a different story than those in the Kara monogatari, despite the presence of the same characters.

\begin{tabular}{|c|c|c|}
\hline Kara monogatari & Source & Meng qiu \\
\hline 1. Wang Ziyou and Dai Andao & Shishuo xinyu 世説新語 & 子猶尋戴 \\
\hline 2. The Pipa Song & Pipa xing 琵琶行 (Bai Juyi) & \\
\hline 3. Jia’s wife & Zuo zhuan 左伝 & 賈氏如泉 \\
\hline 4. Meng Guang, Liang Hong's wife & Hou Han shu 後漢書 & 孟光荊釷* \\
\hline 5. Sima Xiangru and his wife Zuo Wenjun & Shi ji 史記 & $\begin{array}{l}\text { 文君当爐 } \\
\text { 相如題柱 }\end{array}$ \\
\hline 6. Luzhu & Jin shu 晋書 & 緑珠埅樓 \\
\hline 7. Song Yu & Dengtuzi haosefu 登徒子好色賦 & \\
\hline 8. Mianmian, wife of minister Zhang & $\begin{array}{l}\text { Yanzilou sanshou bing fu } \\
\text { 䜩子楼三首並序 (Bai Juyi) }\end{array}$ & \\
\hline \multicolumn{3}{|l|}{ 9. Zhang Wencheng and the Empress Zetian } \\
\hline 10. Deyan and his wife Dame Chen & Ben shishi 本事詩 & \\
\hline 11. Xiao Shi and Longyu & Lie xian zhuan 列仙伝 & 簫史鳳台 \\
\hline 12. The wife who turned into a stone & You ming lu幽明録 & \\
\hline 13. Ehuang and Nuhing, wives of Emperor Shun & Bo wu zi 博物志 & \\
\hline 14. The Concubines of the Mausoleum & Ling yuan qie 陵園妾 (Bai Juyi) & \\
\hline 15. His Lady Li & Li furen 李夫人 (Bai Juyi) & \\
\hline 16. The Queen Mother of the West & Bo wu zhi 博物志 & \\
\hline 17. The Four Sages of Mount Shang and Empress Lü & Han shu 漢書 & 許由一慓 $*$ \\
\hline 18. The Song of Everlasting Regret & Chang hen ge 長恨歌 (Bai Juyi) & \\
\hline 19. Zhu Maichen's wife & Shi ji 史記 & 買妻恥醮 \\
\hline 20. The orphan of Zhao family & Shi ji 史記 & \\
\hline 21. Lord of Pingyuan & Shi ji 史記 & 趙勝謝璧 \\
\hline 22. King Zhuang of Chu & Shuo yuan 説苑 & 楚莊絶縜 \\
\hline 23. Xun Shuang's daughter & Hou Han shu 後漢書 & \\
\hline 24. The White-Haired Woman of the Shangyang Palace & $\begin{array}{l}\text { Shangyang baifa ren 上陽白髪人 } \\
\text { (Bai Juyi) }\end{array}$ & \\
\hline 25. Wang Zhaojun & Xijing zaji 西京雑記 & \\
\hline 26. Pan Anren & Jin shu 晋書 & 岳湛連璧 \\
\hline 27. The two women and the white dog & & \\
\hline
\end{tabular}


The Kara monogatari and the Meng qiu not only have stories in common, but anecdotes 21 and 22 appear in the same order in both works. This has led Kawaguchi Hisao to hypothesize that in writing the Kara monogatari Shigenori based it not on the original sources but on the Meng qiu or other collections containing the same anecdotes. ${ }^{19}$ However, this has not been confirmed by Kawaguchi, or by Ikeda in his extensive and detailed study of the sources of the Kara monogatari. ${ }^{20}$ It is therefore plausible that Shigenori knew the content of the Meng qiu by heart and that he had studied the commentary in vogue in his day. It is in any case clear that he relied on such well-known episodes and characters that their appearance in other sources should come as no surprise.

It is also plausible that the Kara monogatari influenced not only the anthology Kankoji waka shü (mentioned above) but also the production of teaching manuals written in Japanese, namely the three works by Minamoto no Mitsuyuki 源光行 (1163-1244) composed in 1204 and probably dedicated to Minamoto no Sanetomo 源実朝 (1192-1219), who had become the shogun during the previous year. These are the Moggyu waka 蒙求和歌 (Japanese Poems on the Meng qiu), the Hyakuei waka 百詠和歌 (Japanese Poems on Baiershi yong), and the lost Gafu waka 楽府和歌 (Japanese Poems on Yuefu).

Despite being a member of the Minamoto family, Mitsuyuki was above all a man of letters. Having been a pupil of Fujiwara no Shunzei 藤原俊成 (1114-1204), he became famous for his studies on the Genji monogatari; he spent his time between the Heian capital and the new city of Kamakura, where he pursued a career in the shogunate. As he writes in his preface to the Mōgyū waka, as one who has always loved stories and anecdotes, he aims to present them in Japanese so that they may be of use in instructing young people. ${ }^{21}$ Mitsuyuki chooses 150 anecdotes and classifies them into categories, following the practice for poetry anthologies by presenting them in fourteen books. The Chinese verse of four syllables is followed by a commentary in Japanese based on the Chinese commentaries and ends with a waka of the author's own composition. Mitsuyuki's idea is not only to

19 Kawaguchi, Heianchō Nihon kanbungakushi no kenkyū, pp. 973-75.

20 Ikeda, Nitchū hikaku bungaku no kiso kenkyū, pp. 113-56, 441-66.

21 Minamato no Mitsuyuki, Mōgyū waka, p. 74. For the translation of Mitsuyuki's mana and kana prefaces see Guest, "Primers, Commentaries, and Kanbun Literacy," pp. 177-79. teach Chinese culture through Japanese translations of the anecdotes in the Meng qiu, but also to create a manual of poetic composition: he likely intended to provide a guide that would popularize the intellectual pleasure of composing poetry. ${ }^{22}$ Mitsuyuki does the same in the Hyakuei waka, commenting in Japanese on the work of the Tang poet Li Jiao 李嶠 (644-713), the Baiershi yong 百二十詠 (The One-Hundred-and-Twenty Songs), an anthology of poets divided by subject like an encyclopedia and used as a textbook by aristocratic children starting in the Heian period. ${ }^{23}$

It may be assumed that the third work, which has not been preserved, was organized in the same way and contained a commentary on Bai Juyi's New Ballads (Xin yuefu 新楽府) plus a waka for each ballad. ${ }^{24}$ Mitsuyuki made an enormous contribution to the popularity of classical Chinese culture, which until then had been the province of the aristocratic elite in the capital, by spreading it to the warrior class and providing children of samurai with a set of works that met a variety of needs: knowledge of the Chinese language, knowledge of Chinese culture through anecdotes, and the knowledge and skills necessary to write verse in Chinese and Japanese. In short, thanks to Mitsuyuki, we can speak of the first-wave spread of the wa-kan cultural system beyond the palaces of the nobles and the capital.

Based on the prose-and-poetry structure of these two manuals, their inherent purpose of didacticism, and precise textual evidence, Ikeda identified the Kara monogatari as a model on which Mitsuyuki might have based his texts. Ikeda further traced a genealogy of manuals that transmitted the wa-kan cultural system, beginning with the Kara monogatari and including the Muromachi-period Kankoji wakash $\bar{u} .{ }^{25}$ I agree with this hypothesis and would add one more fundamental element that connects the Kara monogatari with the others: their contents are centered on Confucian virtues.

Mitsuyuki was not the only one interested in producing manuals in Japanese. Following a request from the “nun-shōgun” Hōjō Masako 北条政子 (1157-1225),

\footnotetext{
22 Yanase, Mōgyū waka, Hyakuei waka, p. 416.

23 Despite the title, the Hyakuei waka contains 240 poems organized into 120 subjects (dai). The Baiershi yong is also one of the works lost in China (around the Yuan or Ming period) that has survived in Japan.

24 Bai Juyi's New Ballads consist of fifty allegorical poems that criticize social and political injustices. A complete English translation is in Gwither, "Bai Juyi and the New Yuefu Movement."

25 Ikeda, Nitchū hikaku bungaku no kiso kenkyū.
} 
writer Sugawara no Tamenaga 菅原為長 (1158-1246) edited a translation of the Zhenguan zhengyao 貞観政 要 (Essentials of Government of the Zhenguan Reign), the famous manual commissioned by the Tang Emperor Taizong 太宗 (597-649) that became a textbook for state officials both in China and abroad and remained well known in Japan from the Nara period onwards. A vernacular translation, entitled Kana Jōgan seiyō 仮名 貞観政要 (The Zhenguan zhengyao in Kana), was later published in 1647 .

We see this kind of translation activity until the end of the thirteenth century, when Fujiwara no Shigenori 藤原茂範 (n.d.) wrote the Kara kagami 唐鏡 (The Mirror of China), a history of China from ancient times to the Tang period, based on a selection of Chinese historical sources which he fully and faithfully translated with no rhetorical embellishments or subjective considerations, respecting the content and style of the original texts. In this respect, the Kara kagami distances itself from the Kara monogatari and from the works of Mitsuyuki, proving to be not a didactic but a historical work.

In short, translation in medieval Japan ranged from literary to historical and political subjects. Although the production of Chinese texts had moved into a phase of stagnation by the end of the thirteenth centurywhich would incidentally serve as a prelude to a great rebirth during the Edo period - it was still perceived as the "tradition" par excellence, so much so that keeping it alive in Japanese was considered a necessity. As for the Kara monogatari, it can be regarded as one of the first examples of a translation of a Chinese text with a specifically didactic purpose: to transmit classic literary knowledge to female audiences.

\section{Adaptation and Rewriting: Aesthetic Tastes and Buddhist Stances}

In the 1930s, Yamagishi Tokuhei assessed the Kara monogatari as follows: "This work is a model of the art of the translator, who in this case has shown exceptional quality and skill." ${ }^{26}$ In reality, there are very few anecdotes in the Kara monogatari that one could truly consider "translated." We shall see how Shigenori makes

$26 \mathrm{He}$ also claims that the author is unknown and places the work in the Kamakura period. Yamagishi, Yamagishi Tokuhei shosaku shū, p. 299. fairly free use of his sources, cutting or adding narrative elements and even changing, in some cases, the original story. Take for example the second anecdote, whose source is the famous Lute Song, composed in 816 by Bai Juyi. The text is faithfully rendered by the translator, with the exception of the conclusion: in the translation, the poet's decision to live alone and never return to the capital is different not only from the source text but also from Bai Juyi's biography, which was well known at the time in Japan. This is a clear example of how Shigenori altered his sources in order to bring the protagonist closer to the aesthetic ideals of his readers. ${ }^{27}$

The Kara monogatari provides another example of adaptation in anecdote 12, where Shigenori rewrites ex novo a story that takes its cue from a proverbial expression, that of the "rock that contemplates the husband" (bōfuseki 望夫石; Ch. wang fu shi). In the Kara monogatari the story reads as follows:

Long ago there lived a married couple. They were in the prime of life and had sworn to love each other deeply forever, but the man suddenly died. Grief-stricken, the woman came to think that life was no longer worth living. Many suitors competed for her affections, but she refused them all. As she listened to their proposals, all she had in her heart was the image of her husband, whom she did not forget even for a moment. In the end she died and her body turned to stone. ${ }^{28}$

The source of this anecdote is the You ming lu 幽明録 (Records of the Hidden and the Visible Worlds, Six Dynasties Period, 222-589), one of the most important collections of strange tales (zhiguai 志怪), an enduring genre of Chinese fiction. ${ }^{29}$ Although the original

27 In the words of Kanda this represents a process of "medievalization" (chūseika 中世化) of Bai Juyi. Kanda, "Hikaku bungakuteki kenkyū," p. 93. Ikeda sees it as an aristocratic rather than a medievalizing rewriting of the Chinese text. Ikeda, Nitchü hikaku bungaku no kiso kenkyū, p. 108. These opinions do not necessarily conflict, as they agree on a sort of assimilation of Bai Juyi into the Japanese cultural system.

28 昔、おとこ女あひすみけり。としなともさかりにてよろつ行くす急のことまてあさ からす契つありふるに、この夫思のほかにはかなくなりにけり。其後なみた にしつみてあるにもあらすおほえけるを、我もわ枦とねんころにいとみいふ 人ありけれと、いかにもゆるさりけり。これをきくにつけてもなきかげをのみ心 にかけつ、時のまもわするひまなくて、つねにいのちをうなひてけり。そのか はねはいしになりにける. Fujiwara no Shigenori, Kōhon Kara monogatari, p. 17.

29 Despite being traditionally attributed to Liu Yiqing 劉義慶 $(403-444)$, the work is probably the result of a compilation of 
has been lost, the stories it contained were taken up in numerous anthologies. This story appears in the fifth book of Chu xue ji 初学記 (Records for Initial Study, 728 ), an encyclopedia in thirty volumes divided by category, attributed to Xu Jian 徐堅 (659-729), and listed in Nihonkoku genzaisho mokuroku 日本国現在書目録 (Catalogue of Extant Texts in the Country of Japan, 891). This catalogue attests to the presence of the work in Japan by the ninth century:

The You ming lu ... moreover tells us that on a mountain north of Wuchang stands the "rock that contemplates the husband." It has the shape of a person standing. It is said that long ago there lived a faithful bride. The husband was sent on service to a faraway and dangerous region. Taking her children, she climbed the mountain to watch him leave. As she gazed out at her husband, she turned to stone. This is the origin of the name. ${ }^{30}$

The differences between the two stories are evident. The story in the Kara monogatari is certainly not a translation or a rewriting but rather a whole new story that takes its cue from an expression whose origin has been lost. Furthermore, we can see how the source has been transformed to fit the poetic stereotype typical of the Kara monogatari found in other anecdotes (such as nos. 6, 8, and 23) - that of the woman who prefers to die rather than marry another man. ${ }^{31}$

Similarly, anecdote 7 does not translate its Chinese source but rather simplifies it, resulting in a story that is almost meaningless. The anecdote is a rewriting of a fu 賦 (rhapsody) by Song Yu 宋玉 (c. 319-298 BCE),

works by several authors. Zhang, "A Textual History of Liu Yiqing's You Ming Lu."

30 幽明緑[略]又日武昌北山有望夫石、状若人立、古伝云昔有貞婦、其 夫従役、遠赴国難、携弱子䬻送此山、立望夫而化為立石、因以為名焉

Chu xue ji, http://www.guoxue123.com/zhibu/0201/03cxj/004. htm.

31 In Japanese literature, one example of a woman who sees her husband off on a perilous journey and waves to him from afar is found in Man'yōshū 萬葉集 (poems 868, 871-875, 883), where Matsurasayo-hime bids farewell to her husband from afar as he sets out on a mission to the continent. Man'yōshū, pp. 60-63, 65. In Hizen no kuni fudoki 肥前国風土記 (Chronicles of Hizen Province, mid-eighth century), the toponym Matsura is linked to the same tradition. See Hizen no kuni fudoki, p. 278. In neither case, however, is the woman transformed into a rock, nor are there any examples in other early texts. The first example of a wife turning to stone seems to be recorded in Utsuho monogatari 宇津保物語 (The Tale of the Hollow Tree, tenth century). See Utsuho monogatari, p. 74 one of the most famous poets of the Warring States period. In the Kara monogatari, Song Yu is a man of unparalleled beauty and extraordinary erudition. To the eastern side of his home lived a woman, also of unparalleled beauty, who made a commitment to make him fall in love with her. Day and night she would go to the eastern corner of the fence that separated their homes, but three years passed without him so much as glancing at her. Lovesick, she gave way to despair and never managed to meet him. Shigenori concludes:

\section{Song Yu felt no attraction for her, perhaps? Was he perchance too refined to be overwhelmed by love? Or not? It is no easy task to understand the affairs of the heart. ${ }^{32}$}

The fu of Song Yu appears in the Wen xuan 文選 (Literary Anthology, first half of the sixth century) with the title Dengtuzi haosefu 登徒子好色賦 (Rhapsody of Lord Dengtu's Lust). It is a satirical piece, in which Song Yu defends himself from the accusation of lust levelled against him by Dengtu, a minister of the King of Chu. Dengtu advises the king not to take Song Yu with him to the women's rooms, as he is a handsome smooth talker. In reply, Song Yu tells the king that he has been ignoring his beautiful neighbor for three whole years, pointing out that Dengtu, on the other hand, has had five children together with his wife even though she is ugly. ${ }^{33}$ The Kara monogatari version lacks Song Yu's witty comment, making the anecdote not only flat but almost meaningless. ${ }^{34}$

The sources of two of the anecdotes from the collection (nos. 9 and 27) have not been identified and may come from an oral tradition widespread in the days of Shigenori. The first anecdote tells of the love between Zhang Wencheng 張文成 (courtesy name Zhang Zhuo 張鷟, 660-740?), a poet of the Tang period who is traditionally credited with writing the You xian $k u$ 遊仙

\footnotetext{
32 ゆかかからすはなかりけめと、あまり心のいうにて、人に物をおもはせん と思へりけるにや又コもやなかりけん、心のうちしりかたし. Fujiwara no Shigenori, Kōhon Kara monogatari, p. 9.

33 Knechtges, Wen Xuan, Or Selections of Refined Literature, pp. 349-55.

34 The episode of the lady spurned for three years recurs in Hamamatsu chūnagon monogatari 浜松中納言物語 (The Story of the Second Hamamatsu Councilor, eleventh century), where it is attributed to Pan Yue, another character famous for his beauty and the protagonist of anecdote 26 of the Kara monogatari.
} 
窟 (Visit to the Dwelling of the Immortals), ${ }^{35}$ and Empress Wu Zhao 武晊, better known by her posthumous name Zetian 則天 (623-705). Consort of Tang Emperor Gaozhong 高宗 (628-683), she was the first and only woman in China to take the title of emperor ( $d i$ 帝), having founded the Zhou dynasty (690-705). No Chinese source attests to an affair between the empress and the poet; the only other work that mentions it is Japanese, the Hōbutsush $\bar{u}$, which is contemporary with the Kara monogatari. In this version of the story the liaison between $\mathrm{Wu}$ Zhao and the poet, who was said to have given her the You xian $k u$ as a gift, is mentioned very briefly. This does not explain the origin of the information, which perhaps belonged to an oral tradition of the time and was taken up in both works. ${ }^{36}$

The other anecdote for which no source has been found (no. 27) tells of two women who voluntarily renounce the world against their parents' wishes and form a sentimental attachment to a dog. The moral of the tale seems to be that, just as it is impossible to escape the mechanisms of karmic bonds, so too is love, in whatever form, a condition from which there is no escape. What emerges even more clearly in this anecdote is a need to demonstrate how love should be considered one of the obstacles to spiritual growth for those who fall prey to it. ${ }^{37}$

It is evident that Shigenori has manipulated his sources in order to bring the stories closer to the aesthetic tastes of his readership. At this juncture, we cannot help wondering who his readers actually were. If we classify the Kara monogatari as belonging to the setsuwa genre, it must have been meant for educational purposes and could therefore have been a textbook for children. ${ }^{38}$ Nevertheless, even setting aside the fact that the young aristocrats of the time studied Chinese and therefore did not need translations, what could an

35 An English translation can be found in Levy, The Dwelling of Playful Goddesses.

36 Kōda Rohan 幸田露伴 (1867-1947) tried to explain the lack of a Chinese source of reference as an error of mistaken identity committed by the author of the Kara monogatari: the person in question was probably not Zhang Wencheng but perhaps one of the two Zhang brothers, Zhang Yizhi 張易之 or Zhang Changzong 張昌宗, who were court officials at the time of Wu Zhao, or even their father Zhang Xingcheng 張行成, a favorite of the sovereign. Kara monogatari zenshaku, pp. 66-67. In any case, this is merely a matter of conjecture.

37 For more on this anecdote, see Migliore, "Motivi letterari persi e ritrovati in un aneddoto del Kara monogatari."

38 See, among others, Kinoshita, Kara monogatari; Keene, Seeds in the Heart, p. 582 anecdote like no. 27 , for example, teach young people, concerned as it is with the sexual relationship between two young women and a dog?

Another hypothesis might be that Shinegori's ideal reader was female. Indeed, the vast majority of the tales in the Kara monogatari are love stories; the work appears to be a veritable catalogue of love matches with women as protagonists, be they empresses, ladies of the court, or the wives of petits fonctionnaires. Unlike men, by the end of the Heian period women (excluding queens and princesses, women who belonged to the highest ranks of the aristocracy) had no access to a Chinese education. It may therefore be assumed that all other women would have needed a "translation" into Japanese, which featured the addition of waka, a rhetorical style typical of post-Genji monogatari novels, and a Buddhist flavor (as demonstrated by some of the anecdotes, for example nos. 18 and 27). In this sense, we can understand the Kara monogatari as a primer addressed to mid-ranking court women.

On closer inspection, the Kara monogatari does not depict love as something positive. From a Confucian point of view it can be a calamity for the reign or a cause of disorder, in short a sentiment that brings only disaster and pain; and from the Buddhist point of view it prevents rebirth in the paradise of Amida. Several anecdotes are very explicit on this point, particularly no. 15 , in which the death of the consort Li breaks the heart of Emperor $\mathrm{Wu}$, who cannot bring himself to accept his loss. Furthermore, anecdote 18 tells of how Emperor Xuanzong's senseless love for Yang Guifei causes civil war and the death of countless people, leading to the woman's execution. And yet the emperor will not resign himself and resorts to the magical arts, just like Emperor Wu. Both emperors find themselves powerless in the face of the separation caused by death. The inconsolable Xuanzong dies only to be reincarnated again in this world, undergoing the eternal cycle of death and rebirth in order to be with his beloved. As Shigenori points out in the sermon that concludes the anecdote:

Only by renouncing the world and praying for salvation can we safely cross the sea of suffering and come to the land of infinite joy, the Pure Land. ${ }^{39}$

\footnotetext{
39 この世をいとひ、極楽をねかは、くるしみをあつめたるうみをわたりて、楽を きはめたるくにいたらん事はうたかふへからす. Fujiwara no Shigenori, Kōhon Kara monogatari, p. 47.
} 
And again, at the end of anecdote 27, in an attempt to explain how the two women could have become embroiled with a dog, Shigenori concludes:

\section{We all think that we could never find ourselves in a situation like this, and yet, faced with the pro- fundity of a love pact, neither the wise nor the fool can escape their fate. ${ }^{40}$}

This underlines that the only road to salvation is the renunciation of love. However, it is a negative feeling only if it binds us to the flesh: pure love is rewarded, as in the case of the two lovers in anecdote 11, musician Xiao Shi 簫史 and Lung Yu 弄玉, the daughter of the duke, who live immersed in art, far from the filth of the world, and fly together to Heaven. ${ }^{41}$

It is remarkable how similar this narrative is to those contained in Buddhist anecdotes produced in the late Heian and Kamakura periods, where love is seen as a deeply sinful practice but nonetheless arouses pathos. I am referring in particular to anecdotes contained in Hosshinshū 発心集 (Collection of Tales of Religious Awakening) by Kamo no Chōmei 鴨長明 (1155?-1216) and Kankyo no tomo 閑居友 (Companion in Solitude, 1222?) by the monk Keisei 慶政 (1189-1268), which deal with the theme of amorous love between men and women. ${ }^{42}$ The reshaping of secular anecdotes in a religious context reveals the contiguity of Kara monogatari to the religious and aesthetic ideals that dominated Heian and Kamakura writings, further corroborating the spread of a hybrid wa-kan culture.

\section{Confucian Virtues: Devoted Wives, Foolish Ladies}

The most common theme in the collection is that of devoted wives, who appear as protagonists in no fewer than eight anecdotes (nos. 4, 5, 6, 8, 10, 12, 13, 23).

40 いかはかりかは、このみちにいらしと思とりしかと、契のふかきにあひぬれ は、かしこきもはかなきもさなからのかれかたき事にや. Fujiwara no Shigenori, Kōhon Kara monogatari, p. 69.

41 The source of the anecdote is the Lie xian zhuan 列仙伝 (Biographies of Immortals), a collection of seventy anecdotes about characters ranging from ancient times to the Han period. It is traditionally attributed to Liu Xiang 劉向 (77-76 BCE) but was certainly written later. See Kaltenmark, Le Lie-sien Tchouan. In Japan it is listed in the Nihonkoku genzaisho mokuroku.

42 For a discussion see Pandey, Perfumed Sleeves and Tangled Hair, in particular pp. 132-36.
Anecdote 4 tells of Liang Hong 梁鴻 (fl. 24-80) (3 $^{4}$ and his wife Meng Guang 孟光. The Kara monogatari describes her as "an ugly woman like no other in the world" whereas the Chinese source, the Hou Han shu 後漢書 (The History of the Later Han, 432) merely speaks of a strong woman, strong enough to lift a stone mortar, who appeared in public without makeup or ornaments. Indeed, Meng Guang eschews the frills that make women beautiful, preferring warm, comfortable clothes suited to life in the woods, just as her husband wishes. In the Chinese tradition their union is celebrated as an example of the perfect marriage.

In anecdote 5, Zhuo Wenjun 卓文君 (second century BCE), daughter of a wealthy merchant and poetess, married the jobless Sima Xiangru 司馬相如. Even though she was forced to lead a miserable life, she did not abandon her husband and remained faithful to him. This couple, too, was traditionally celebrated as an example of a perfect marriage in numerous Chinese sources.

Ehuang 娥皇 and Nüying 女英 (anecdote 13), the two brides of the legendary Emperor Shun 舜, weep tears of blood at his death. ${ }^{44}$ In anecdote 10 , a couple separate due to economic hardship. When they meet again, the woman is now the wife of a man of high social status, but she does not hesitate to leave him and return to her hometown to be with her first husband. ${ }^{45}$ Mianmian 眪眪 (anecdote 8) remains faithful to her

43 Liang Hong embodies one of the most famous examples of a man of letters eschewing all contact with power, even rejecting an invitation from the emperor. In China, withdrawal from the world by men of letters was a common phenomenon from ancient times, especially among Daoist and Confucian thinkers, encompassing more than one ethical and political meaning, and expressing the concept that the hermitical life is the only means to protect one's moral integrity. See Berkowitz, Patterns of Disengagement, in particular pp. 106-12. Meng Guang's biography is also found in Xu Lienü zhuan 続列女伝 (Supplemental Biographies of Exemplary Women), the eighth and last book of Lienü zhuan (Biographies of Exemplary Women) by Liu Xiang, the oldest Chinese work dedicated exclusively to the moral education of women, which celebrates chaste and devout brides, upright widows, and loving mothers. This work would become the reference textbook for female education in China for the next two millennia. Kinney, Exemplary Women of Early China.

44 The source of the anecdote can be found in Bo wu zi 博物志 (Encyclopedic Treatise), attributed to Zhang Hua 張華 (232-300), a court official and poet of the Jin Dynasty. The work is listed in the Nihonkoku genzaisho mokuroku.

45 The source of the anecdote is the Ben shi shi 本事詩 (Poems and Their Origins, 886), compiled in the year 886 by Meng Qi 孟棨 ( $\mathrm{fl}$ $841-886)$; it is a collection of forty-one anecdotes, organized into categories, which explains the reasons for the composition of so many poems, almost all by poets from the Tang period. 
husband's memory and dies twelve years later without remarrying. A young wife dies of grief after losing her husband, and her body turns into stone (anecdote 12, see above); Lüzhu 綠珠 chooses to leap from a tower rather than fall into the hands of her beloved's enemy (anecdote 6), while Xun Shuang's wife, forced by her parents to remarry after becoming a widow, hangs herself on the day of her wedding (anecdote 23). In quite the opposite sense, we find a negative example in the story of the wife of Zhu Maichen 朱買臣 (anecdote 19), who refuses to share a life of hardship with her husband and dies of shame when she discovers that he has become governor.

Furthermore, women who rely on beauty alone, which is of course ephemeral (as the ugly but wise Meng Guang of anecdote 4 well knew), and remain heedless of cultivating other virtues such as modesty or prudence, are punished by fate. This is what befell the lady confined in the mausoleum in the Palace of Shangyang (anecdote 14), a rewriting of an allegorical poem by Bai Juyi, the Ling yuan qie 陵園妾 (The Ladies of the Mausoleum), in which ladies banished from the court and left to age in a remote dwelling are none other than honest officials treated unjustly. Not only does this theme wholly disappear in the Kara monogatari, but also the narrative flow is not faithful to the original source: indeed, it is a rewriting that preserves only the poetic motif of the woman who has been separated from her affections and the places dear to her. We find exactly the same in anecdote 24 , whose source is, again, a yuefu by Bai Juyi entitled Shangyang baifa ren 上陽 白髪人 (The White-haired Lady of Shangyang) that denounces the sorry state of the ladies of the imperial harem while referring to neglected court officials. Here, also, the critical intent of the poet in the Kara monogatari disappears to leave room only for the description of the women's sad fate.

The story of Wang Zhaojun 王照君 (anecdote 25), one of the most popular in the entire repertoire of Chinese legends, relates the tragic destiny of a court lady forced to leave her home and parents to spend a miserable life in the uncivilized Xiongnu 匈奴 land, her beauty and refined manners wasted on a husband unable to appreciate them. The Kara monogatari is utterly critical of Wang Zhaojun's behavior:

She did not guard against the wickedness that lurks in the hearts of men, but had trusted only the transparency of a mirror that reflected her beauty. ${ }^{46}$

In the Kara monogatari story, Wang Zhaojun is presented as lacking wisdom, since she is unable to protect herself from the improper behavior of others. She lacks virtue since she relies on her beauty alone. ${ }^{47}$

Dismayed by her husband's ugliness, the wife of the capable Jia did not smile for three years, but she changed her mind when she saw his prowess as an archer and found Confucian wisdom after three years of unreasonable foolishness (anecdote 3 )..$^{4}$ The wife of the lord of Pingyuan 平原, who laughs at a crippled soldier and is executed for it (anecdote 21), is truly thoughtless.

On the contrary, the male protagonists are all outstanding in their indisputable virtues. They include highly refined and illustrious men of letters, like Wang Ziyou 王子崷 and his friends Dai Andao 戴安道, Bai Juyi, Song Yu and Pan Anren 潘安仁 (who were also famous for their beauty), and Zhang Wencheng, whose discretion sets him apart (anecdotes 1, 2, 7, 9, and 26 respectively). We also have an example of faithful ministers who make the supreme sacrifice to honor their lord (anecdote 20), not to mention wise ministers devoted to wise emperors, all models of true Confucian behavior (anecdotes 17 and 22).

As the above summary demonstrates, it is precisely virtue that constitutes the main theme of the whole collection-a Confucian virtue, of course, honoring the loyalty of the subject to the lord, the devotion of the bride to the groom, the subjection of children to parents; a virtue whereby sovereigns are compassionate, ministers are wise, and women are devoted wives and good mothers who prefer wisdom to ephemeral

46 この人はかみみのかの〈もりなきをのみたのみて、ひとのこンろのにこれるを しらす. Fujiwara no Shigenori, Kōhon Kara monogatari, p. 65.

47 This same ethical judgement of Wang Zhaojun's foolish behavior is shared in Konjaku monogatari. For a more detailed discussion see Migliore, "Some Notes on Ō Shōkun Legend."

48 This anecdote appears for the first time in Zuo zhuan 左伝 (Memoires of Zuo), in the section on the twenty-eighth year of Duke Zhao (513). It is also included in the anonymous Diaoyuji 琱 玉集 (The Shining Jade Collection), a collection of anecdotes in fifteen books organized by subject, which seems to have been compiled around the beginning of the Tang period. It is one of several works lost in China but handed down in Japan, where there exists only one handwritten copy of books twelve and fourteen, dated 747, housed in Shinpukuji 真福寺 in Nagoya. The anecdote about Jia's wife ends with a note giving its source as the Zuo zhuan. We also find the story in Mengqiu. There are no substantial differences among the three versions or in the rendering of the Kara monogatari. 
beauty. Buddhism also seems to be overshadowed by these themes, and emerges as no more than a hollow repetition of essential concepts, such as avoiding links with the things of this world, including an exaggerated love for women, and praying for rebirth in the paradise of the Pure Land.

A negative example stands out in the behavior of Emperor $\mathrm{Wu}$ in anecdote 16 , in which the emperor shows himself to be too involved in the human world; frightened by the idea of death, and revealing in so doing his lack of wisdom, he tries to obtain the elixir of immortality. When he is visited by the goddess Xiwang $\mathrm{mu}$ 西王母, the Queen Mother of the West, he asks her, too, but receives a humiliating answer:

You are born in the human word, subject to birth, aging, sickness, and death. How could you ask me for the elixir of immortality? How foolish! ${ }^{49}$

Shigenori then archly comments:

Words such as these, whether addressed to the Queen Mother of the West or to a dullard like me, do not seem worthy of a wise and holy emperor of past times..$^{50}$

Shigenori's harshness is striking not only because he makes fun of an emperor, caught in a moment of weakness that ill behooves the dignity of his role, but also because it is a clear criticism of Daoist beliefs which were part of a very long and highly respected tradition in China yet never really esteemed in Japan. Elsewhere in the anecdote, Dongfang Shuo 東方朔, the immortal exiled on Earth, even acts as a comic interlude: he hides under the floor but is immediately discovered by Xiwang mu. Lastly, the other Daoist immortal in the story is called Illusion (maboroshi 幻), which further emphasizes the inconsistency of Daoist beliefs.

A Daoist immortal called Illusion is also found in anecdote 18. He goes to the land of the immortals to meet Yang Guifei as a messenger between the two lovers. Yet, as Shigenori writes, "All that is in this world

49 生老病死の下界にむまれ給なから、いかてかふしのくすりをもとめさ せ給へき。はかなき御心なり. Fujiwara no Shigenori, Kōhon Kara monogatari, p. 24.

50 西王母のみにあらす、かひなきおろかなる心にも、かしのかしこきひしり の御門の御こと葉とはおほえす. Fujiwara no Shigenori, Kōhon Kara monogatari, p. 24. is just a dream and an illusion." ${ }_{51}$ To follow the foolish Daoist illusions, which claim to prolong life or create bonds even after death (like the incense that evokes the spirit of the dead in anecdote 15), ${ }^{52}$ means to remain tied to this world of suffering and block one's entry to the Pure Land. While this comment seems quite heartfelt compared to the others of a religious nature that are scattered throughout the collection, given the strong Confucian strain dominating the whole compilation it still feels too much like a pious formula to be truly sincere. Only at the end of the Yang Guifei story (no. 18) can we find a passage recognizable as a sermon; elsewhere, at the end of anecdote 27 , Shigenori suggests that the relationship between the women and the dog is the result of relationships fostered in past lives. It is true that Buddhist detachment from sensual love, and in general from the material world (as in the case of Emperor $\mathrm{Wu}$ ), enables spiritual elevation, but the principal theme of the Kara monogatari, continuously and visibly traceable in all the stories, is the claim to Confucian virtues a woman should nurture.

Another strong note of criticism in the Kara monogatari has to do with some Chinese customs that Shigenori considers devoid of compassion, above all brutality that leads to the death of innocent people. The most touching case is that of the killing of Yang Guifei (anecdote 18), to which Shigenori adds the following comment:

Even the trees and herbs, which have no feelings,
changed color; even the birds and wild animals,
which do not know compassion, shed tears. ${ }^{53}$

Again, in anecdote 21, Lord Pingyuan's favorite wife is put to death because she laughs at a crippled old soldier:

Sacrificing a beautiful woman for just one soldier, and a cripple to boot, is completely heartless. Yet this is not an isolated example. According to Chinese custom, not even an emperor opposes

\footnotetext{
51 おほよそこの世はみなゆめまほろしのことし. Fujiwara no Shigenori, Kōhon Kara monogatari, p. 47.

52 Incense that brings back the dead (fan hun xiang 返魂香) only works for a few moments. This incense is only mentioned in two texts: the Shizhou ji 十洲記 (Chronicles of the Ten Continents) and the Bo wu zi. See Pregadio, The Encyclopedia of Taoism, pp. 898-99.

53 物のあはれをしらぬ草木まても色かはり、なさけなきとりけたものさへ涙をな かせり. Fujiwara no Shigenori, Kōhon Kara monogatari, p. 38.
} 
the wishes of one of his soldiers, even the most humble. ${ }^{54}$

Criticism found in the Kara monogatari indicates a very precise stance. In these cases the author, albeit celebrating Confucian virtues, clearly distances himself from the Chinese tradition, making the point that such acts of barbarity would not have happened in Japan. As for Daoism, Shigenori refuses to celebrate the "great tradition" and proposes instead the Japanese "way," which certainly preferences Buddhism, in terms of detachment from the human world and of compassion for all living beings. This amounts to a rejection of some of the "Chinese traditions" (karakuni no narai からくにのな らひ), ${ }^{55}$ confirming that the wa-kan cultural system did not take shape in an uncritical way.

\section{Conclusion}

In the hierarchy of classical Japanese literature, the Kara monogatari undoubtedly occupies a secondary position compared to other works that have enjoyed greater success and therefore greater attention from scholars. However, this work unequivocally reveals how far Chinese culture was inextricably linked to the process of the production of Japanese culture and the degree to which Chinese culture helped to enrich Japanese culture by becoming part of it.

In the same way, by including the most famousand celebrated-Chinese stories in a form influenced by Japanese literary practices, Shigenori presents the notion that these stories are in fact part of the Japanese cultural heritage, despite having been expressed in Chinese until he created his text. For example, when Wang Zhiyou is asked why he returns without meeting his friend Dai Andao (anecdote 1), Wang answers with a waka. Spouses who meet again after a separation, ladies in the grip of loneliness, lovers suffering from the cruelty of separation, and Bai Juyi himself (!) all recite waka. Rewriting Chinese culture in Japanese only confirms the appropriation.

The most remarkable feature of the Kara monoga-

54 あしなへたるつかはれ人ひとりに、かほうつくしきをかへけるも、いとなさけ なきしわさなりや。おほかたこれならす、からくにのならひにて、あやしきもの、 ふなれと、いひたちねる事を、みかともそのこっろさしをは、やふらせ給はぬに や. Fujiwara no Shigenori, Kōhon Kara monogatari, pp. 56-57. 55 Fujiwara no Shigenori, Kōhon Kara monogatari, pp. 12, 57 tari, however, is to be found in a common thread running through the anecdotes, that of feminine Confucian virtues: conjugal faithfulness, loyalty, and prudence. Empresses, ladies of the court, officials, and commoner wives all share the same concerns about correct Confucian behavior, the same acceptance of feminine virtues widely praised since the most ancient times. On the other hand, the author does not spare severe criticism toward those women who act thoughtlessly by, for example, behaving imprudently or relying only on their own beauty.

The fact that one or more elements that also belong to the Chinese tradition are rejected is not surprising as it confirms that cultural assimilation did not take place wholesale in an uncritical way, but rather through intense and vital intellectual activity that reached such a degree of maturity that it was possible to choose some elements and omit others. The unevenness of this process contributed to the wealth of Japanese literary heritage.

The Kara monogatari acts as a bridge between the Heian and Kamakura cultures and, like the Mōgyu waka and other educational works mentioned above, it played a role in the spread of culture from the aristocratic to the military class. It is therefore not surprising that it transmits Confucian values and at the same time is also imbued with the monogatari-like literary rhetoric that was so in vogue in the late Heian period as a consequence of the enormous success of Genji monogatari. The Kara monogatari is a synthesis of the two faces of the aristocratic culture of the period.

Of course, spreading culture to other social classes inevitably brings with it a certain trivialization, a flattening of the content. The most indicative example of this process is anecdote 7. Song Yu's witticism, around which the original source hinges, disappears in the Japanese version, and in the conclusion of the anecdote one almost perceives the embarrassment of Shigenori himself, unable to explain why the man lets three years pass without taking any notice of his beautiful neighbor. Anecdote 4 is another example. Meng Guang simply becomes ugly and obliging, whereas in the original source she is a woman with a strong personality who rejects stereotypes and is prepared to wait for a husband worthy of her. The transformation of Bai Juyi's personal story (anecdote 2) does not depend on a rewriting of the Chinese text in a medieval or aristocratic sense, as has been said, but is instead a trivialization designed to meet the literary and rhetorical tastes of the readers of 
the time. Lastly, when in anecdote 12 it becomes possible to create a new story from scratch to justify the use of a common expression whose origin has probably been lost, the author recycles the same old story of a woman languishing in pain who refuses all other suitors, preferring to become a rock. The original source is much more moving: here the woman becomes a rock so she can accompany her spouse with her gaze until he disappears over the horizon and ultimately has the privilege of seeing him return before anyone else could.

In Japan, the transition from an aristocratic society to a military one, far from the capital and the court, marked an important moment in the country's history. The Kara monogatari embodies this change, spreading culture through a process of inevitable simplification, but nonetheless still acting as a Confucian primer for women's correct behavior and facilitating the transmission of social, cultural, and literary knowledge to a broader audience.

\section{Reference List}

\section{- Abbreviations Used}

KST Shintei zōho kokushi taikei 新訂増補国史大 系. 66 vols. Yoshikawa Kōbunkan, 1929-1964.

NKBT Nihon koten bungaku taikei 日本古典文学大 系. 102 vols. Iwanami Shoten, 1958-1968.

SNKBT Shin Nihon koten bungaku taikei 新日本古典 文学大系. 100 vols. Iwanami Shoten, 1989-.

SNKZ Shinpen Nihon koten bungaku zenshū 新編日 本古典文学全集. 88 vols. Shōgakukan, 1994-.

\section{- Primary Sources}

Bai Juyi ji 白居易集. Ed. Gu Xuejie 顧学頡. Zhonghua Shuju, 1979.

Chu xue ji 初学記. http://www.guoxue123.com/ zhibu/0201/03cxj/004.htm.

Diaoyuji 琱玉集. Ed. Yanase Kiyoshi 柳瀬喜代志 and Yahagi Takeshi 矢作武. Chōgyokushū chūshaku 琱玉集 注釈. Kyūko Shoin, 1985.

Fujiwara no Shigenori 藤原成範. Kara monogatari zenshaku 唐物語全釈. Ed. Kobayashi Yasuharu 小林保治. Kasama Shoin, 1998.
Fujiwara no Shigenori 藤原成範. Kōhon Kara monogatari 校 本唐物語. Ed. Ikeda Toshio 池田利夫. Kasama Shoin, 1975.

Fujiwara no Shigenori 藤原茂範. Kara kagami 唐鏡. Ed. Yoshida Kōichi 吉田幸一 and Hirasawa Gorō 平沢五郎. Koten Bunko, 1967.

Hizen no kuni fudoki 肥前国風土記. In vol. 3 of Nihon koten o yomu 日本古典を読む, ed. Kojima Noriyuki 小島憲之 et al., pp. 272-81. Shōgakukan, 2007.

Man'yōshū 万葉集. SNKZ 7 .

Minamoto no Mitsuyuki 源光行. Hyakuei waka 百詠和歌. In vol. 15 of Zoku Gunsho Ruiju 続群書類従, pp. 151-85. Zoku Gunsho ruiju kanseikai, 1931.

Minamoto no Mitsuyuki 源光行. Mōgyū waka 蒙求和歌. In vol. 15 of Zoku Gunsho Ruiju 続群書類従, pp. 74-150. Zoku Gunsho ruiju kanseikai, 1931.

Nihonkoku genzaisho mokuroku: Shūshō to kenkyū 日本国現 在書目録 : 集証と研究. Ed. Yajima Genryō 矢島立亮. Kyūko Shoin, 1984.

Nihon sandai jitsuroku日本三代実録. KST 4.

Taira no Yasuyori 平康頼. Hōbutsushū 宝物集. SNKBT 40. Tsūken nyūdō zōsho mokuroku 通建入道蔵書目録. In vol. 21 of Shinkō Gunsho ruijū 新校群書類従, pp. 545-54. Naigai Shoseki, 1930.

Utsuho monogatari 宇津保物語. NKBT 11.

\section{- Secondary Sources}

Berkowitz, Alan J. Patterns of Disengagement: The Practice and Portrayal of Reclusion in Early Medieval China. Stanford University Press, 2000.

Bowring, Richard. "Review" (Ward Geddes, Kara monogatari: Tales of China). Bulletin of the School of Oriental and African Studies 48:3 (1985), pp. 586-87.

Denecke, Wiebke. Classical World Literatures: Sino-Japanese and Greco-Roman Comparisons. Oxford University Press, 2014.

Geddes, Ward. Kara monogatari: Tales of China. Arizona State University, Center for Asian Studies, 1984.

Guest, Jennifer. "Primers, Commentaries, and Kanbun Literacy in Japanese Literary Culture, 950-1250 CE.” PhD dissertation, Columbia University, 2013.

Gwither, Jordan Alexander. "Bai Juyi and the New Yuefu Movement." PhD dissertation, University of Oregon, 2013.

Ikeda Toshio 池田利夫. Nitchū hikaku bungaku no kiso kenkyū 日中比較文学の基礎研究. Kasama Shoin, 1974. 
Kaltenmark, Max. Le Lie-sien Tchouan: Biographies légendaires des immortels taoïstes de l'antiquité. Collège de France (1953), 1987.

Kanda Hideo 神田秀夫. "Hikaku bungakuteki kenkyū (chūsei)”比較文学的研究 (中世). Kokubungaku kaishaku to kanshō 國文學解釋と鑑賞21 (1956), pp. 90-95.

Kawaguchi Hisao 川口久雄. Heianchō Nihon kanbungakushi no kenkyū 平安朝日本漢文学史の研究. Meiji Shoin, 1990.

Keene, Donald. Seeds in the Heart. Columbia University Press, 1999.

Kinney, Anne. Exemplary Women of Early China: The Lienü zhuan of Liu Xiang. Columbia University Press, 2014.

Kinoshita Motoichi 木下資一. Kara monogatari 唐物語. In vol. 3 of Kenkyu shiryō Nihon koten bungaku 研究資料日 本古典文学, ed. Ōsone Shōsuke 大曽根章介 et al. Meiji Shoin, 1984.

Knechtges, David R. Wen Xuan, Or Selections of Refined Literature. Princeton University Press, 1996.

Konishi, Jin'ichi. A History of Japanese Literature. Volume Two: The Early Middle Ages. Princeton University Press, 1986.

Levy, Howard S. The Dwelling of Playful Goddesses. Dai Nippon Insatsu, 1965.

Midorikawa Fumiko 翠川文子. Kara monogatari 唐物語. In vol. 3 of Taikei monogatari bungaku shi 体系物語文学史, ed. Mitani Eiichi 三谷栄一,pp. 532-44. Yūseidō, 1983.

Migliore, Maria Chiara. Kara monogatari: Racconti cinesi. Milano: Edizioni Ariele, 2015.

Migliore, Maria Chiara. "Motivi letterari persi e ritrovati in un aneddoto del Kara monogatari." In Studi in onore di Luigi Polese Remaggi, ed. Giorgio Amitrano, Lucia Caterina, and Giuseppe De Marco, pp. 289-96. Napoli: Università degli Studi di Napoli "L’Orientale," Dipartimento di Studi Asiatici, Series Minor LXIX, 2005.

Migliore, Maria Chiara. "Some Notes on Ō Shōkun Legend.” Gogaku kyōiku kenkyū ronsō 語学教育研究論 叢 23 (2006), pp. 261-76.

Mimura Terunori 三村晃功. “Kankojidai waka kara mita chūsei ruidaishū no keifu” 漢故事題和歌からみた中世 類題集の系譜. In vol. 13 of Wakan hikaku bungaku sōsho 和漢比較文学叢書, ed. Wakan Hikaku Bungakukai 和 漢比較文学会, pp. 67-82. Kyūko Shoin, 1992.

Ōta Shōjirō 太田晶二郎. “'Sōka shoshi’ shosai 'Koseki kasho mokuroku”’桑華書誌」所載「古跡歌書目録」. Nihon gakushiin kiyō日本学士院紀要 12:3 (1954), pp. 169-86.
Pandey, Rajyashree. Perfumed Sleeves and Tangled Hair: Body, Woman, and Desire in Medieval Japanese Narratives. University of Hawai'i Press, 2016.

Persiani, Gian-Piero. "China as Self, China as Other: On Ki no Tsurayuki's Use of the Wa-Kan Dichotomy." SinoJapanese Studies 23 (2016), pp. 31-58.

Pregadio, Fabrizio, ed. The Encyclopedia of Taoism. London and New York: Routledge, 2008.

Smits, Ivo. "The Way of the Literati: Chinese Learning and Literary Practice in Mid-Heian Japan." In Heian Japan, Centers and Peripheries, ed. Mikael Adolphson, Edward Kamens, and Stacie Matsumo, pp. 105-28. University of Hawai'i Press, 2007.

Yamagishi Tokuhei 山岸徳平. Yamagishi Tokuhei shosaku $s h \bar{u}$ 山岸徳平署昨集. Vol. 5. Yūseidō, 1972.

Yanase Kiyoshi. Mōgyū waka, Hyakuei waka 蒙求和歌·百 詠和歌. In vol. 5 of Setsuwa no kōza 説話の講座, ed. Honda Yoshinori 本田義憲 et al., pp. 413-32. Benseisha, 1993.

Zhang, Zhenjun. “A Textual History of Liu Yiqing's You Ming Lu." Oriens Extremus 48 (2009), pp. 87-101. 